\section{International Scientific Journal Theoretical \& Applied Science}

\author{
p-ISSN: 2308-4944 (print) e-ISSN: 2409-0085 (online) \\ Year: 2015 Issue: 01 Volume: 21 \\ Published: $30.01 .2015 \quad$ http://www.T-Science.org
}

\section{Anna A. Sokolova}

student,

Financial University under the Government of the

Russian Federation (Kaluga Branch), Russia sokolova073@mail.ru

SECTION 31. Economic research, finance, innovation, and risk management.

\title{
THE DEVELOPMENT OF INFRASTRUCTURE APK IN THE REGION ON THE EXAMPLE OF KALUGA REGION
}

Abstract: The article analyzes the development of the infrastructure of agriculture to re-regional level by the example of the Kaluga region. The study conclusions and proposals to address the problems identified.

Key words: regions, agribusiness, agriculture, socio-economic development, Kaluga region.

Language: Russian

Citation: Sokolova AA (2015) THE DEVELOPMENT OF INFRASTRUCTURE APK IN THE REGION ON THE EXAMPLE OF KALUGA REGION. ISJ Theoretical \& Applied Science 01 (21): 76-79. doi: http://dx.doi.org/10.15863/TAS.2015.01.21.13

\section{РАЗВИТИЕ ИНФРАСТУКТУРЫ АПК В РЕГИОНЕ НА ПРИМЕРЕ КАЛУЖСКОЙ ОБЛАСТИ}

Аннотация: В статье проанализировано развитие инфраструктуры агропромышленного комплекса на региональной уровне на примере Калужской области. По итогам исследования сделань выводы и предложения, направленные на решение выявленных проблем.

Ключевые слова: регионы, апк, сельское хозяйство, сочиильно-экономическое развитие, Калужская область.

Развитие - поступательное движение, эволюция, переход от одного состояния к др., включающее глубокие изменения во всех сферах общества. Феномен развития стал предметом самостоятельного исследования целого ряда научных направлений и школ в середине прошлого столетия.

Стратегия экономического развития, ориентированная на аграрный сектор, должна состоять из трех элементов:

1) ускорение роста сельскохозяйственного производства за счет мер повышению производительности за счет мер по повышению производительности сельскохозяйственных предприятий на основе совершенствования технологий;

2) увеличение спроса на сельскохозяйственную продукцию;

3) комплексное развитие села [1, с.29].
В современной экономической структуре России агропромышленному комплексу (АПК) принадлежит очень существенная роль.

Комплекс обладает огромным производственным потенциалом, в первую очередь из-за размеров занимаемых площадей, а также благодаря плодородию почв, климатическим условиям регионом и человеческому капитала.

В структуре земельного фонда Калужской области земли сельскохозяйственного назначения составляют 1 млн. 820,1 тыс. га, в том числе сельскохозяйственные угодья - 1 млн. 145,2 mыс. 2a.

Численность постоянного населения на начало 2014 года - 1004,8 тыс. чел, в т.ч. сельского 242,2 тыс. чел. или $24,1 \%$ от общей численности. 


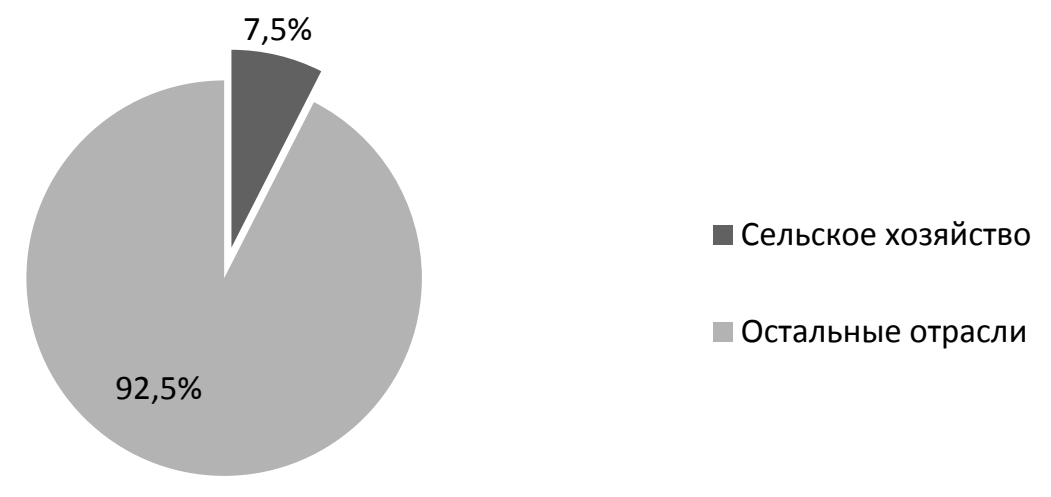

Рисунок 1 - Удельный вес сельского хозяйства в ВВП Калужской области.

Агропромышленный комплекс как целостная, «интегрированная хозяйственная система.

Основанная на взаимодействии в едином воспроизводственном процессе факторов и продуктов ряда отраслей и сфер в создании общего конечного продукта из сельскохозяйственного сырья для удовлетворения общественных потребностей»[2], представляет собой совокупность четырех взаимосвязанных подсистем:

I сфера - отрасли производящие и поставляющие факторы производства для сельского хозяйства;

II сфера - аграрное производство;

III сфера - отрасли переработки сельскохозяйственной продукции;

IV сфера - интегральная инфраструктура комплекса.

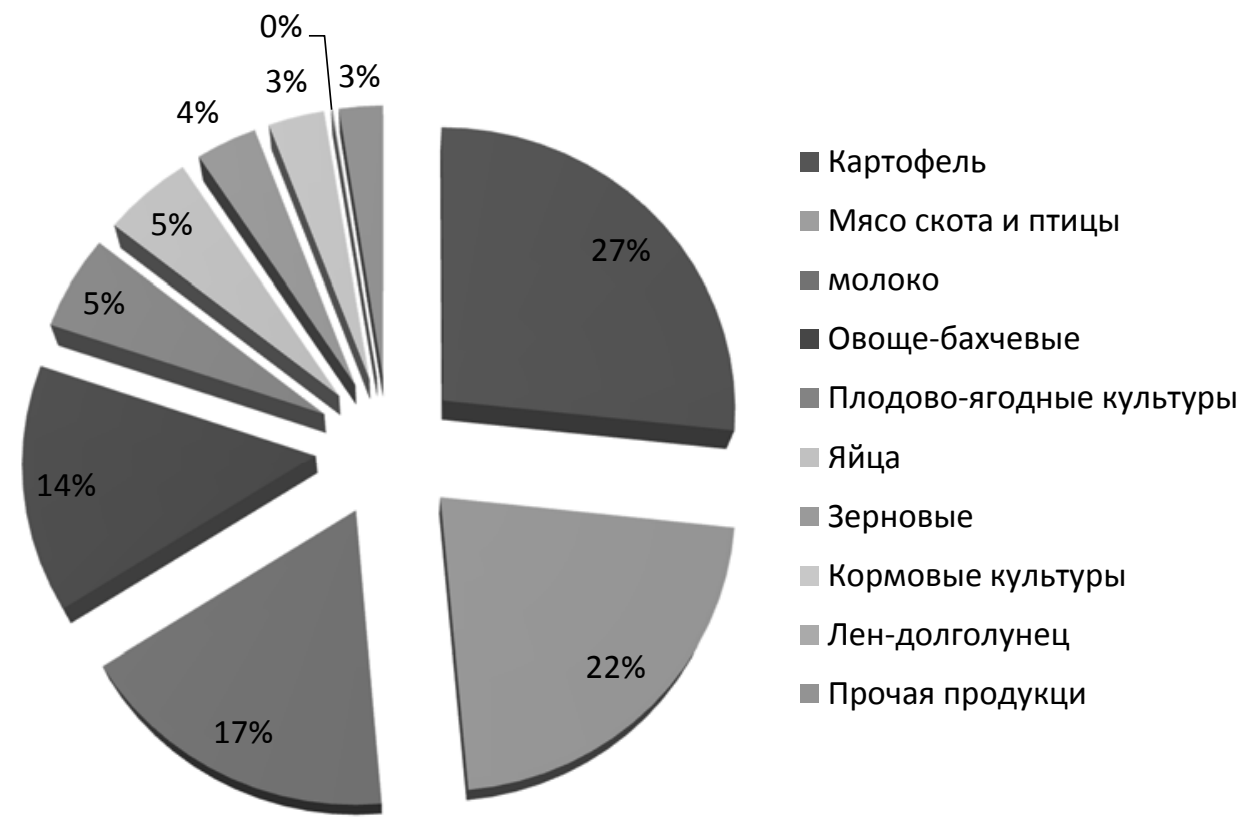

Рисунок 2 - Структура сельского хозяйства в 2013 году.

Являясь частью инфраструктуры экономики, инфраструктура агропромышленного комплекса способствует созданию общих предпосылок воспроизводственного процесса, общих условий роста и развития агропромышленного

ISPC European Science,

Linköping, Sweden производства, что выступает наиболее существенным признаком. Конкретизирующим еe экономическую природу. Содержание инфраструктуры агропромышленного комплекса выражается в экономических отношениях, 
возникающих между инфраструктурными субъектами, с одной стороны, и другими хозяйствующими субъектами и сельским населением, пользующимися услугами инфраструктуры, - с другой. Эти отношения складываются по поводу: создания условий воспроизводства факторов производства; оказания торгово-посреднических, кредитнофинансовых, информационно-рекламных и прочих видов услуг; распределения и перераспределения материальных, финансовых, трудовых ресурсов и доходов.

Агропромышленный комплекс Калужской области представлен большим количеством крупных и малых сельскохозяйственных предприятий. Особенности ландшафта и большое количество лугов и пастбищ определило основные направления развития сельского хозяйства области - молочно-мясное хозяйство и овощеводство с картофелеводством. Большое значение здесь играет непрерывное поступательное развитие пищевой промышленности области, туристической и рекреационной инфраструктуры, - с расширением рынка сбыта, растет и производство сельскохозяйственных товаров.

В состав агропромышленного комплекса Калужской области входят 219 организачий, осущчествляющих сельскохозяйственную деятельность, 45 крупньх $и$ средних предприятий пищеевой $u$ перерабатьвающчей промышленности, 750 крестьянских

(фермерских) хозяйств, $101 \quad 000$ личньх подсобных хозяйств.

Как видно из представленной на рисунке 1 диаграммьл в в 2013 году удельный вес сельского хозяйства в ВВП Калужской области составил $7,5 \%$, что на 0,6\% ниже аналогичного показателя в 2012 году.

Если рассмотреть подробнее структура продукции сельского хозяйства (рис.2), то видно, что в 2013 году наибольший удельный вес имеет производство картофеля - 27\%, следом идет производство мяса скота и птицьь - 22\%.

Как видно, структура сельского хозяйства сильно дифференцирована, это может говорить о исторически сложивщейся специализации нашего региона. Животноводство является одной из ведущчих отраслей АПК, а в результате возрастающего числа роботизированных ферм в Калужской области о в скором времени оно может занять лидируюшие место.

Агропромышленному комплексу всегда уделяется большое внимание, разрабатьваются и применяются на практике различные программа поддержки и развития сельского хозяйства. В числе последних таких программ Государственная программа Калужской области "Развитие сельского хозяйства и регулирования рынков сельскохозяйственной продукции, сырья и продовольствия в Калужской области", утвержденная Постановлением Правительства Калужской области от 5 декабря 2013 года №654 «Об утверждении Государственной программы Калужской области "Развитие сельского хозяйства и регулирования рынков сельскохозяйственной продукции, сырья и продовольствия в Калужской области"». Это программа направлена на : повышение эффективности развития рынков сельскохозяйственной продукции; повышение уровня рентабельности в сельском хозяйстве для обеспечения его устойчивого развития; создание условий для эффективного использования земель сельскохозяйственного назначения[3].

Однако, при этом следует значительное внимание уделять и проводимой долговой политике. Как показало проведенное ранее исследование, в Калужской области государственный долг на душу населения вырос вдвое - с 8,39 тыс. рублей до 16,37 тыс. рублей [4, с.221]. Кроме того, проведенная комплексная оценка социально-экономического развития Калужской области показала, что на улучшение социально-экономического развития Калужской области положительное влияние оказывает рост инновационной и инвестиционной привлекательности, который будет продолжаться и в дальнейшем [5,c.296].

В заключении можно сделать вывод, что в современном мире агропромышленный комплекс имеет большое значение для общества. В калужской области в последнее время можно наблюдать положительную тенденцию развития АПК. Сейчас уровень сельскогохозяйства высок, но недостаточен, чтобы удовлетворить возрастающие потребности населения. В структуре АПК еще сохраняются диспропорции, которые необходимо устранить.

Научное исследование проведено под руководством кафедры - «Экономика», Калужский филиал Финансового университета при Правительстве Российской Федерации, Россия. 


\section{References:}

1. GV Timofeeva (2003) «Razvitie infrastrukturyi APK kak faktor pod'ema otechestvennogo selskogo hozyaystva». Vestnik Volgogradskogo gosudarstvennogo universiteta. Seriya 3: Ekonomika. Ekologiya. 2003. \# 8. pp. 29-32.

2. Inshakov OV (2012) «Mehanizm sotsialnoryinochnoy transformatsii i ustoychivosti razvitiya APK Rossii» - Volgograd: Izd-vo Volgogradskogo gos. universiteta, pp.35.

3. (2015) Gosudarstvennaya programma Kaluzhskoy oblasti "Razvitie selskogo hozyaystva i regu-lirovaniya ryinkov selskohozyaystvennoy pro-duktsii, syirya i prodovolstviya v Kaluzhskoy oblasti".

4. Balyinin IV (2014) Kompleksnyiy analiz dolgovoy politiki $\mathrm{v}$ ramkah reytingovoy otsenki sub'ektov Rossiyskoy Federatsii po urovnyu riska nesbalansirovannosti regionalnyih byudzhetov. Ekonomika i predprinimatelstvo. 2014. \# 5-1. pp. 217-222.

5. Balyinin IV (2013) Kompleksnaya otsenka sotsi-alno-ekonomicheskogo razvitiya Kaluzhskoy ob-lasti. Mirovoe soobschestvo: problemyi sotsi-alno-ekonomicheskogo i duhovno-politicheskogo razvitiya Sbornik nauchnyih sta-tey Vserossiyskoy nauchnoprakticheskoy kon-ferentsii. Finansovyiy universitet pri Pravi-telstve RF (Novorossiyskiy filial); Pod re-daktsiey L.S. Andriyanovoy. Penza, 2013. pp. 289-298.

6. Balyinin IV (2014) Kompleksnaya model otsen-ki riskov nesbalansirovannosti byudzhetov sub'ektov Rossiyskoy Federatsii v kontekste sotsialno-ekonomicheskogo razvitiya regionov. Audit i finansovyiy analiz, 2014, \# 3, pp. 316-319.

7. VorobYov NN, VorobYova EA (2011) Tendentsii razvitiya predprinimatelstva $\mathrm{v}$ agrobiz-nese vostochnoy zonyi Stavropolskogo kraya. Ekonomicheskie issledovaniya. 2011. \# 7. pp. 4.

8. Gorodetskiy PV (2010) Sostoyanie proizvodstva i obespechenie produktsiey selskogo hozyaystva goroda Krasnoyarska i osnovnyie napravleniya razvitiya prigorodnogo selskogo hozyaystva. Vestnik Novosibirskogo gosudarstvennogo agrarnogo universiteta. 2010. T. 4. \# 16. pp. 93-98.

9. Kirsanova OV (2014) Mehanizmyi razvitiya malogo i srednego biznesa v selskom hozyaystve. Nauchnoe obozrenie. 2014. \# 5. pp. 279-283.

10. Troshin AS, Rastopchina YL, Saharova OS (2014) Tendentsii razvitiya agrarnogo sekto-ra ekonomiki Rossii na sovremennom etape. Nauchnoe obozrenie. 2014. \# 9-2. pp. 592-597.

11. (2015) Ministerstvo selskogo hozyaystva. Available: http://www.mcx.ru/ (Accessed: 15.01.2015).

12. (2015) Federalnaya sluzhba gosudarstvennoy statistiki. Available: http://www.gks.ru/ (Accessed: 15.01.2015). 